\title{
We Lost the Greatest... Our Maradona (or Pele)
}

\author{
Jorge Mura ${ }^{1}$ \\ 1 University of Chile, Santiago, Chile \\ Arq Bras Neurocir 2021;40(1):16-17.
}

We lost one of the most gifted neurosurgeons of modern history in neurosurgery, and I am not stating that just because I happened to be one of his Fellows (year of 1998), but because I really knew him in and out of scrubs. I remember him being difficult and distant at times, and extremely demanding. He had a good and bright side which was known by most, but he also had his dark days, which only a few of his inner circle knew. However Dr. Evandro de Oliveira was a necessary person for his time, worked all of his life for neurosurgery and left us while fighting heroically against a terrible disease such as amyotrophic lateral sclerosis, which left him without one of his most precious virtues, his voice. With the power of the spoken word, he was able to convince anyone easily. When in 1996 I heard him speaking about the beauty of vascular neurosurgery, microsurgical anatomy and micro-neurosurgery I felt the calling from within my soul, which continues to be true now 20 years later.

We had worked continuously with Dr.Evandro throughout my career which started in 1998. Shortly after coming back from Brazil we kept our collaboration active with more than 100 article reviews and some original research articles I had the honor to co-author with him. Dr de Oliveira came to Chile in the year 2000, at the time that I was presenting my candidacy to enter the Chilean neurosurgical Society. He was a frequently invited as honored guest in our Chilean neurosurgical Congress, which we acknowledged with a foreign honorary member distinction in 2007. I vividly remember when he came to Chile for the Latinamerican Neurosurgery Congress in 1998. During the Congress I felt blessed to make a connection with him which finally brought me to Brazil with him for a few months: an experience that would change my life.

Dr. de Oliveira was an extremely generous man, a person that knew how to help those who had passion to improve themselves within neurosurgery. He was also intolerant to mediocrity and conformism. His excellence and body of work became the beacon of Latin American neurosurgery in the world's map.

His passing leaves a huge void in me. There are great friends that are suffering much more than myself however, such as Pablo Rubino. Dr Rubino was one of his closest disciples and his" neurosurgical son". My thoughts also go for his great collaborators such as Helder Tedeschi and Wen Hung Tzu.

Dr. de Oliveira was able to combine the microsurgical mastery of Dr. Yasargil with the exceptional neuroanatomy teachings of Dr. Rhoton, a combination I consider the core of neurosurgery.

He left an incredible legacy of Latinamerican neurosurgery as well as worldwide neurosurgery and it is the duty of all of us, but specifically of his disciples, to honor his memory. I would urge anyone that is passionate about microneurosurgery, vascular neurosurgery, skull base or even those who, from other subspecialties, love good neurosurgery to not settle for less than perfection. I urge you to strive for surgical excellence and to respect and treat our field the way $\mathrm{Dr}$ de Oliveira taught us to: be righteous, prepare well for surgery, know how to defend a surgical strategy, a novel idea, respect for our colleagues and our discipline, be passionate, and above all, to love neurosurgery.

Dr de Oliveira was an extremely charismatic figure, and even though at the end he lost his voice, he continues alive within the field he so well helped developed. We recently honored him through a symposium of the American society of neurosurgery in San Diego, and through the creation of the microsurgical laboratory of the "Beneficiencia Portuguesa de Sao Paulo", which is named after him. In all of these events, we - his colleagues and
Address for correspondence Jorge Mura, MD, IFAANS, FACS, University of Chile, Santiago,

DOI https://doi.org/ $10.1055 / \mathrm{s}-0041-1730272$ ISSN 0103-5355.

Chile

(e-mail: jorgemuramd@gmail.com). (c) 2021. Sociedade Brasileira de Neurocirurgia. All rights reserved. This is an open access article published by Thieme under the terms of the Creative Commons Attribution-NonDerivative-NonCommercial-License, permitting copying and reproduction so long as the original work is given appropriate credit. Contents may not be used for commercial purposes, or adapted, remixed, transformed or built upon. (https://creativecommons.org/ licenses/by-nc-nd/4.0/)

Thieme Revinter Publicações Ltda., Rua do Matoso 170, Rio de Janeiro, RJ, CEP 20270-135, Brazil 
disciples- as well as all the souls he touched directly or indirectly gave him a deeply felt acknowledgement and kept his voice alive.

I would like to underline one of Dr de Oliveira's greatest obsessions: teaching. He had the habit of recording all of his surgeries to evaluate all his surgical mistakes (even in his most perfect operations), which he then would use during his famous courses. I was lucky enough to attend several of his courses, which taught me greatly. I have adopted his passion to teach, which I have applied towards my Fellows, residents and trainees. I am profoundly grateful to Dr de Oliveira for showing me the power behind teaching and investing in future generations. I am convinced that this valuable lessons were fundamental in my professional development, and especially in my last recognition as "Maestro de la Neurocirugia" of Chile last year... thank you Dr de Oliveira.

Dr de Oliveira's legacy is international. Here in Chile we have a deeply rooted influence from him, not only in the way we think about neurosurgical technique but also in the form of fellowships inspired after him, through which I trained close to 50 neurosurgeons since 2000 .

I believe his passing is an enormous loss. However Dr de Oliveira is immortal in neurosurgery, as his teaching will pass over generations and we, his trainees, will make sure his name and memory stand proud for the generations to come.
The day I knew of Dr de Oliveira's passing was especially heartfelt for me. I happened to be operating an arteriovenous malformation, which was one of Dr de Oliveira's preferred surgeries. During surgery I had vivid memories of the surgical moves he had taught me, which guided me during the operation, just like if he himself would speak to me from above. He used to call me one of "Evandro's Boys" and now I feel a huge responsibility to persist in my strive for teaching and technical perfection as these were the fields he taught me the most. His generosity is unparalleled. Although I know this quality of him will be declared by many, I had the opportunity to experience his human qualities and generosity during a very hard situation back in 1998, which brought me very close to him, and helped develop myself as the neurosurgeon I am.

I'd like to conclude by expressing my most heartfelt and sincere gratitude for Dr de Oliveira, and for all the good and tough moments I shared with him, which equally made me better as a person and neurosurgeon. In summary Dr de Oliveira was an absolute master, a giant neurosurgeon, great person and embodied that which in our culture like to call "an Imprescindible"... He is our Maradona, our Pele... the greatest of all is gone.

Conflict of Interest

None. 